\title{
Groundwater simulation in Dak Lak province based on MODFLOW model and climate change scenarios
}

Groundwater simulation in Dak Lak

Nguyen Ngoc An, Huynh Song Nhut, Tran Anh Phuong, Vu Quang Huy, Nguyen Cao Hanh and Giang Thi Phuong Thao Ho Chi Minh City Institute of Resources Geography, VAST, Ho Chi Minh, Vietnam Pham The Trinh Dak Lak Department of Science and Technology, Buon Ma Thuot, Vietnam, and Pham Viet Hoa and Nguyễn An Bình Ho Chi Minh City Institute of Resources Geography, VAST, Ho Chi Minh, Vietnam

\begin{abstract}
Purpose - Groundwater plays a critical part in both natural and human existence. When surface water is scarce in arid climates, groundwater becomes an immensely valuable resource. Dak Lak is an area that frequently lacks water resources for everyday living and production, and the scarcity of water resources is exacerbated during the dry season. As a result, it is critical to do study and understand about groundwater to meet the region's water demand. This study aims to extend the use of the MODFLOW model for groundwater simulation and assess the overall groundwater reserves and water demand in the highland province Dak Lak. Design/methodology/approach - The MODFLOW model is used in this work to compute and analyze the flow, prospective reserves of groundwater from which to plan extraction and estimate groundwater variation in the future.

Findings - The application of the MODFLOW model to Dak Lak province demonstrates that, despite limited data, particularly drilling hole data for subterranean water research, the model's calculation results have demonstrated its reliability and great potential for use in other similar places. The use of the model in conjunction with other data extraction modules is a useful input for creating underground flow module maps for various time periods. The large impact of recharge and evaporation on groundwater supplies and water balance in the research area is demonstrated by simulations of climate change scenarios RCP4.5 and RCP8.5. Originality/value - None of the studies has been done previously to analyze water resources of Dak Lak and the scarcity of water resources is exacerbated during the dry season. Therefore, this study will provide useful insights in the water resource management and the conservation of Dak Lak. The groundwater in Dak Lak can meet the area's water demand, according to the results obtained and water balance in the study area. However, the management of water resources and rigorous monitoring of groundwater extraction activities in the area should receive more attention.
\end{abstract}

Keywords MODFLOW, Groundwater, Dak Lak, Climate change scenarios

Paper type Research paper

(C) Nguyen Ngoc An, Huynh Song Nhut, Tran Anh Phuong, Vu Quang Huy, Nguyen Cao Hanh, Giang Thi Phuong Thao, Pham The Trinh, Pham Viet Hoa and Nguyễn An Bình. Published in Frontiers in Engineering and Built Environment. Published by Emerald Publishing Limited. This article is published under the Creative Commons Attribution (CC BY 4.0) licence. Anyone may reproduce, distribute, translate and create derivative works of this article (for both commercial and non-commercial purposes), subject to full attribution to the original publication and authors. The full terms of this licence may be seen at http://creativecommons.org/licences/by/4.0/legalcode.

This study was supported by the project "Assessment of changes in groundwater resources for agricultural production in the context of climate change in Dak Lak province" under the program of Dak Lak Department of Science and Technology (2019-2021). The authors also would like to thank Dak Lak Department of Science and Technology for funding the research project.

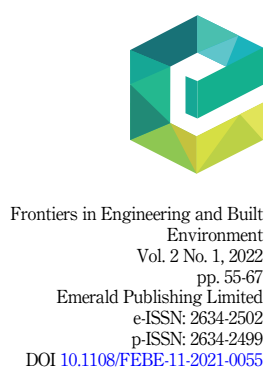


FEBE

2,1

\section{Introduction}

With three river systems, the Serepok, Ba and Dong Nai, and high average annual rainfall, Dak Lak has plenty of surface water (Jeremy and Jeff, 2005; Japan International Cooperation Agency (JICA), 2018; World Bank, 2019). Nonetheless, with industrial deposits of Grade C2 in the Buon Ma Thuot plateau, the groundwater source on basalt is relatively large (Japan International Cooperation Agency (JICA), 2018). During the dry season, however, the surface resource is essentially non-existent. Instead, groundwater becomes the primary source of water for more than half of the province's domestic and agricultural activities, including irrigating coffee plantations (Ellen et al., 2015; Dave et al., 2005). As a result, coupled with the current climate change situation, people's everyday lives and output are substantially impacted, making the matter even more stressful and critical (Dave et al., 2005; Ahmad, 2000; Fortunel, 2000).

In the case of groundwater representation and calculation, MODFLOW is one of the most powerful models, as it has numerous applications in more than 90 countries (Nasrin et al., 2013; Waterloo Hydrogeologic, 2018a; USGS, 1997; Feng et al., 2010). While successful applications have been demonstrated in different countries, the model has been used for groundwater research in several places in Vietnam, mainly focusing on plain areas with negligible elevation differences.

Assessment of the applicability of the MODFLOW model for calculating and forecasting subterranean water reserves in the plains of Quang Tri province demonstrated a significant correlation between calculated results and in situ measurements in both stable and unstable operating conditions. The study area's static and dynamic natural reserve results are generally compatible with prior research (Anh et al., 2009).

By combining the MODFLOW with spatial data of topography, geology and hydrometeorology, the calibrated model showed a significant improvement compared to validation data. The natural dynamic reserves account for $40.0 \%$ (approximately $54,313.68 \mathrm{~m}^{3} / \mathrm{day}$ ) and $60.0 \%$ for natural static reserves. Potential exploitation reserves are $135,594,3 \mathrm{~m}^{3} /$ day and are evenly spread throughout all three aquifers, highlighting the potential exploitation reserves in Quang Nam province's coastal plain are slightly less than adjacent areas (Trung et al., 2019).

Assessment of subterranean water resources in Me Kong delta, a case study in Tra Vinh province, using the MODFLOW model forecasted a -9.5 and $3.9 \mathrm{~m}$ decline in the water level, respectively. Additionally, the findings of this study contribute to elucidating the hydrodynamic properties of aquifers, laying the groundwork for the future establishment of a monitoring network for groundwater dynamics (Hiep and Ty, 2012).

Prediction of groundwater flow in Con Son Island under climate change scenarios showed that the water level in the Pleistocene aquifer near coastal areas increased well over $1 \mathrm{~m}$. The difference in the water level throughout the whole area is inconsiderable and even. Noticeably, research also concluded that the amount of precipitation-based recharge has a significant effect on the groundwater balance compared to the effect of sea-level rise (Trang et al., 2016).

In this study, we aim to extend the use of the MODFLOW model for groundwater simulation in the highland province Dak Lak. We implemented the groundwater model through the visual MODFLOW graphical interface, allowing for an assessment of the province's overall groundwater reserves and water demand. Additionally, the study suggests strategies for planning, exploiting and strategically using groundwater in the future to develop sustainable agricultural output.

\section{Data and method}

Figure 1 represents the proposed methodology for groundwater simulation using MODFLOW models. Each step is further detailed in the sections below. 


\subsection{Study area}

Dak Lak province is located in the Central Highlands and covers an area of $13,125.4 \mathrm{~km}^{2}$, constituting $27.6 \%$ of the Central Highlands' total area and $3.9 \%$ of the country's natural area. It is located between $107^{\circ} 28^{\prime} 57^{\prime \prime} \mathrm{E}$ and $108^{\circ} 59^{\prime} 37^{\prime \prime} \mathrm{E}$ and $12^{\circ} 9^{\prime} 45^{\prime \prime} \mathrm{N}$ and $13^{\circ} 25^{\prime} 06^{\prime \prime} \mathrm{N}$ geographical coordinates. The province is bounded on the north by Gia Lai province, on the south by Lam Dong province, on the east by Phu Yen and Khanh Hoa provinces and on the west by Cambodia and Dak Nong provinces. Dak Lak's terrain descends from Northwest to Southwest, with an average elevation of $400-800 \mathrm{~m}$. The climate of the province as a whole is classified into two subregions. During the dry season, the Northwest has a hot and dry environment, while the East and South have a mild and temperate climate (Jeremy and Jeff, 2005).

\subsection{Methods}

The MODFLOW model is particularly suitable for modelling the condition of groundwater movement and balance with the goal of assessing the evolution of groundwater resources for agricultural output in Dak Lak province. Water Resources Applications Software (USGS, 1997 ) is the world's most common model for calculating the reserve, quality and distribution of subsurface flows. The open-access software package allows users to run tests and calibrate models to obtain very accurate results. A major point of the model is that the input data parameters can be visualized and adjusted continuously during the simulation. The following equation describes the overall variance in groundwater level (Michael and Arlen, 1988):

$$
\frac{\partial}{\partial x}\left(K_{x x} \frac{\partial h}{\partial x}\right)+\frac{\partial}{\partial y}\left(K_{y y} \frac{\partial h}{\partial y}\right)+\frac{\partial}{\partial z}\left(K_{z z} \frac{\partial}{\partial z}\right)-W=S_{s} \frac{\partial h}{\partial t}
$$

where

$K_{x x}, K_{y y}, K_{z z}$ are permeability parameters in the $x, y, z$ directions, respectively;

$h$ is the head height at position $(x, y, z)$ at time $t$;

$W$ is the amount of groundwater recharge or extraction at position $(x, y, z)$ at time $t$; and

$S_{S}$ is the specific storage.

Equation (1) describes the water level dynamics under heterogeneous and anisotropic environmental conditions together with boundary conditions and initial conditions of the aquifer forming a mathematical model of groundwater stream. The model's inputs are hydro-meteorological boundary conditions, hydrogeological parameters of aquifers in the study area. The inputs are calibrated by monitoring water level at boreholes and observation wells. The output of the model is the water level contours of the aquifers from which analytic formulas are applied to calculate the results of underground water reserves.

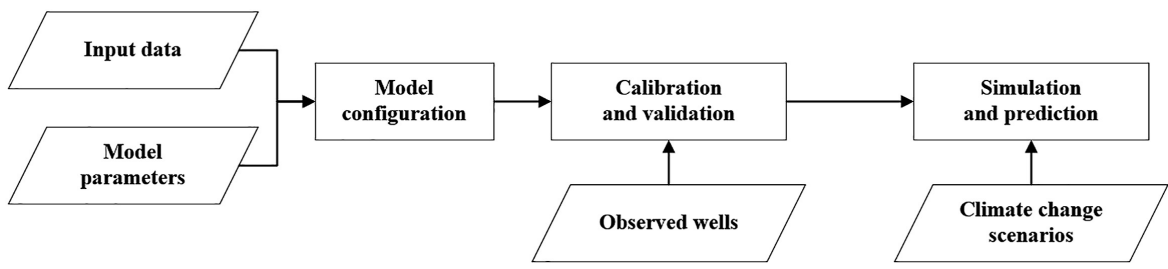

Figure 1.

Workflow for groundwater simulation in Dak Lak province

Groundwater simulation in Dak Lak 


\section{FEBE} 2,1

\section{8}

\section{Results}

\subsection{Model configuration}

To conduct simulation configuration, the model requires some inputs, including the boundaries of the study area, regional topographic elevation, data on aquifers, exploitation wells and groundwater level observation wells, data sources on dry boundary conditions, river edges, streams, reservoirs. In addition, weather data sources such as rainfall, evaporation and update amounts are used for simulation calculations.

From data on topography and aquifers, the study area is divided into a network of cells with the size of $1 \times 1 \mathrm{~km}$ for each cell, specifically 114 rows and 113 columns with 12,882 cells. Simulation model of four main aquifers in Dak Lak (Ellen et al., 2015; Nawapi; Resource base and environment, 2015) is as per the detail provided in Table 1.

The amount of recharge and evaporation: the initial value is selected according to the data of the average monthly precipitation of the hydro-meteorological station until 2020 combined with the soil and rock particles in each area, the slope of the terrain and the vegetation cover. The amount of recharge is usually taken as $20-30 \%$ of the total annual average rainfall in the study area and is determined by the inverse problem and gradually tested during the adjustment process. Evaporation data were entered into the model including two parameters: maximum evaporation amount and evaporation limit depth (in this study, $6 \mathrm{~m}$ was chosen for the whole area) (Hoori Ajami, 2020; Mary et al., 2015).

Extraction flow: based on reports as well as borehole data and reported data on water demand in the study area in 2020, giving a value of exploitation flow for each basin.

Boundary conditions: considering rivers, streams and reservoirs in the area, rivers in the region possibly have more interaction with groundwater. The direction and amount of water depend on the water level inequality and the permeability resistance of the material accumulated in the riverbed. River borders are placed at these locations to simulate the amount of groundwater draining into the river or vice versa. The water level on these outskirts is the river level determined by the data of the monitoring stations. The permeability coefficient $(\mathrm{C})$ is calculated according to the seepage coefficient and river width.

Observation well system: provides the necessary information to determine the general rules of groundwater dynamics. In the model, this observed water level data will not participate in the calculation, but only act as a measure to evaluate the accuracy of the solutions of the problems compared to reality.

\subsection{Model calibration and validation}

Match-up exercises measure the model's accuracy through calibrated and validated steps using a total of 15 observed wells over the research area. We evaluated the models using absolute residual mean, root mean squared and normalized root mean squared following the

\begin{tabular}{lll}
\hline Layers & Name & Description \\
\hline 1 & $\begin{array}{l}\text { Holocene } \\
\text { sedimentary }\end{array}$ & Thickness $0.5-20 \mathrm{~m}$, usually $2-3 \mathrm{~m}$ \\
2 & $\begin{array}{l}\text { Pleistocene } \\
\text { sedimentary }\end{array}$ & $\begin{array}{l}\text { Thickness } 5-40 \mathrm{~m} \text {, usually } 10-30 \mathrm{~m} \text {, with the permeability coefficient } \\
\text { ranging from } 0.2 \text { to } 8 \mathrm{~m} / \text { day }\end{array}$ \\
& $\begin{array}{l}\text { Basalt aquifer (BN2- } \\
\text { QI) }\end{array}$ & $\begin{array}{l}\text { Thickness } 40-240 \mathrm{~m} \text {, usually } 80-120 \mathrm{~m} \text {; permeability coefficient } 0.004- \\
\text { 4,304 m/day }\end{array}$ \\
& Jura sedimentary & $\begin{array}{l}\text { Form in general at a depth of over } 200 \mathrm{~m} \text { and has a normal permeability } \\
\text { coefficient of less than } 0.1 \mathrm{~m} / \text { day }\end{array}$
\end{tabular}

Table 1.

Description of groundwater layers in 4 Dak Lak provinces 
suggestion of Waterloo Hydrogeologic (2018). Formulation of statistical metrics is provided below:

(1) Absolute residual mean:

$$
|\bar{R}|=\frac{1}{n} \sum_{i=0}^{n}\left|\overline{R_{1}}\right|
$$

(2) Root mean squared: RMS:

$$
\mathrm{RMS}=\sqrt{\frac{1}{n} \sum_{i=1}^{n} R_{i}^{2}}
$$

(3) Normalized root mean squared:

$$
\text { Normalized RMS }=\frac{\text { RMS }}{\left(X_{\text {obs }}\right) \max -\left(X_{\text {obs }}\right) \min }
$$

where:

(1) $R_{i}$ : error at observation well $i$;

(2) $n$ : number of observation wells in simulation;

(3) $\left(X_{\text {obs }}\right)_{\max }$ : observation well with the largest value; and

(4) $\left(X_{\text {obs }}\right)_{\min }$ : observation well with the smallest value.

Figure 2 represents the performance of MODFLOW model after the calibration process. Overall, the model resulted in well performance as all error metrics and linear regression presented in the linear regression model. Across all metrics, Pearson's linear correlation coefficient $\left(R^{2}=0.987\right)$ indicates the high correlation between the measured and estimated values. Other statistics also give the high accuracy $(|\bar{R}|=19.52 \mathrm{~m}, \mathrm{RMS}=23.0052 \mathrm{~m}$ and normalized RMS $=4.088 \%$ ), resulting in the promising predictions while MODFLOW-based groundwater modelling in Central highland province Dak Lak.

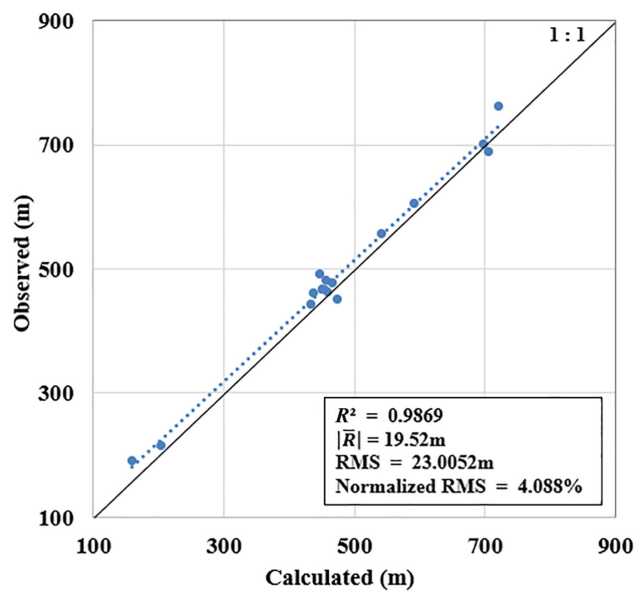

Figure 2.

Comparison of measured and calculated water level elevations at wells 


\section{FEBE 2,1}

60

\subsection{Simulation results}

Table 2 shows the simulation results after one year as well as daily consumption. Statistics indicate that groundwater reserves in Dak Lak province are relatively large, guaranteeing the supply for domestic and livelihood activities in the area. The total reserve of rainwater in the province is about 5 billion $\mathrm{m}^{3} /$ year (Hieu, 2006), and the amount groundwater compensated by rainfall is calculated at about 1.2 billion $\mathrm{m}^{3} /$ year, accounting for about $25 \%$ of the total reserve (Hoori Ajami, 2020; Mary et al., 2015). The annual evaporation volume is relatively large, about 1.5 billion $\mathrm{m}^{3} /$ year due to the high altitude (Japan International Cooperation Agency (JICA), 2018). The difference of input and output reserves has positive values, which shows that the amount of groundwater in Dak Lak meets the demand over the observed period.

3.3.1 Water level. The areas assessed with the highest proportion of potential reserves are located in the south, while the remaining largest reserves belong to the north (Figure 3 ). With the potential of groundwater in these regions in addition to providing water for domestic use, it has the potential to provide both industrial and agricultural production.

Figure 4 shows the water head value at total of four aquifers in Dak Lak following the time steps of 30,60 and 365 days. Over time, all aquifers show a depletion in both mountainous and highland areas, leading to the remarkable decline in a short time of exploitation. Although the reserve of groundwater in the area is relatively rich, it is challenging to monitor the exploitation and use of water, leading to a shortage of water sources for production and daily life, especially in the dry season.

3.3.2 Water equivalent calculation. Table 2 infers that the main factors involved in the water equivalent process are local water reserves, inflows and outflows, replenishment, river water and evaporation. The statistics also highlight that the reservoir factor does not involve much in the water equivalence process and only accounts for a very small proportion of

\begin{tabular}{lcrrr}
\hline & \multicolumn{2}{c}{ Yearly } & \multicolumn{2}{c}{ Daily } \\
Variables $\left(\mathrm{m}^{3} \times 10^{4}\right)$ & In & Out & In & Out \\
\hline (1) Storage & $257,949.4$ & $74,840.9$ & 704.8 & 204.5 \\
(2) Constant head & $159,377.6$ & $125,743.4$ & 435.5 & 343.6 \\
(3) Pumping well & 0.0 & $22,520.4$ & 0.0 & 61.5 \\
(4) River leakage & $13,467.8$ & $123,017.5$ & 36.8 & 336.1 \\
(5) Evapotranspiration & 0.0 & $149,138.4$ & 0.0 & 407.5 \\
(6) Recharge & $120,995.4$ & 0.0 & 330.6 & 0.0 \\
(7) Lake seepage & 152.1 & 30.7 & 0.4 & 0.1 \\
Total (1+2+3+4+5+6+7) & $551,942.30$ & $495,291.40$ & $1,508.04$ & $1,353.26$ \\
Potential reserves (Total In - Total Out) & \multicolumn{2}{c}{$56,650.9$} & & 154.8 \\
\end{tabular}

Figure 3.

Static water level in each simulation period
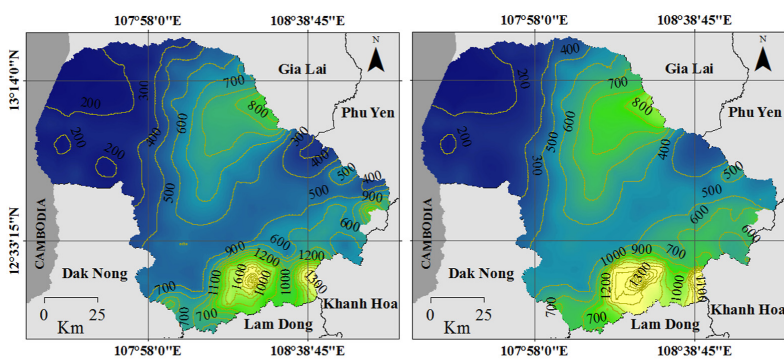

155

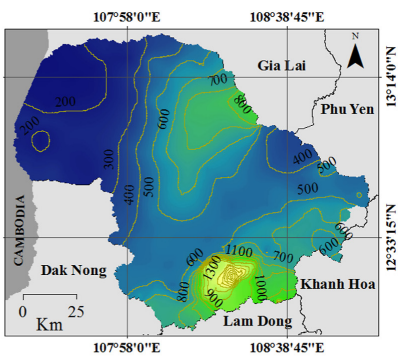

$1900(\mathrm{~m})$ 

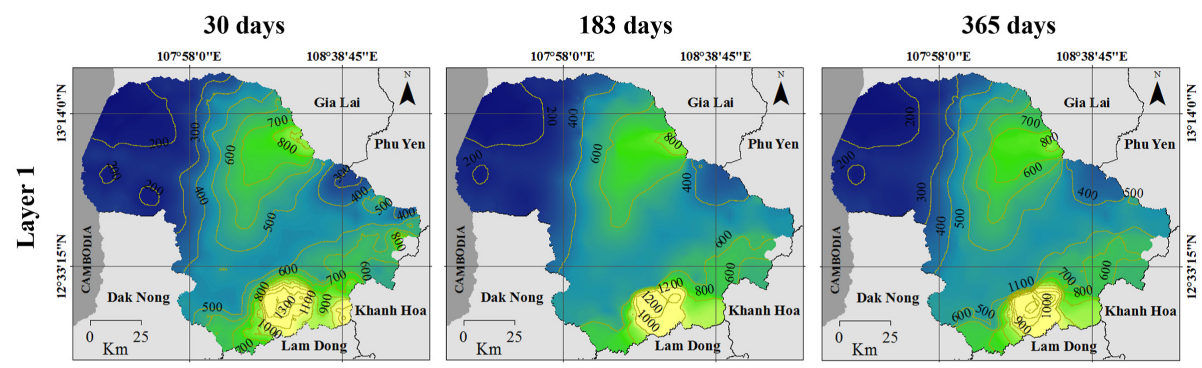

Groundwater simulation in Dak Lak
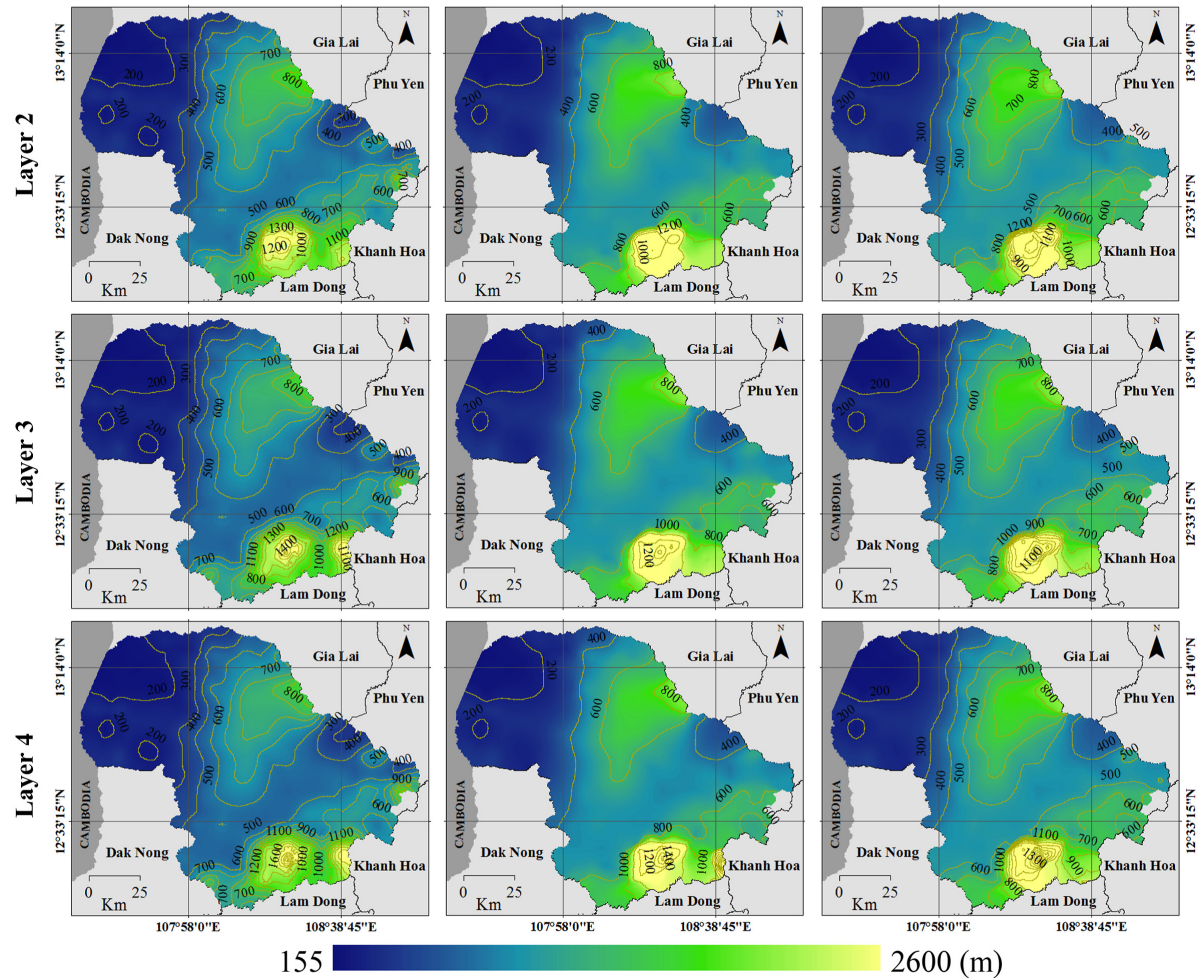

Figure 4. Head water at four layers in each simulation period

the water resource allocation. The amount of water remaining after the process is the potential exploitation in the area. Additionally, the current extraction is still under the allowable limit.

Although the data from the model prove that groundwater in Dak Lak can meet the demand for water twice the current demand, water shortage in the province has increased gradually in recent years.

\subsection{Climate change scenario}

The latest scenario on climate change and sea level rise for Vietnam was developed and announced by the Ministry of Natural Resources and Environment in 2016 with two main scenarios, RCP4.5 (medium climate change scenario) and RCP8. 5 (highest climate change scenario). This study focuses on analyzing and evaluating the change of temperature and 
FEBE 2,1

precipitation over time because these are two factors that have a direct impact on the evolution of groundwater resources in the context of climate change. The temperature and rainfall in Vietnam have the following changes:

Temperature: According to the RCP4.5 scenario, at the beginning of the century, the average annual temperature across the country had a common increase from 0.6 to $0.8^{\circ} \mathrm{C}$. By mid-century, the increase was from 1.3 to $1.7^{\circ} \mathrm{C}$. The northern region (Northwest, Northeast, Northern Delta) had an increase of $1.6-1.7^{\circ} \mathrm{C}$ when that of the North Central region fluctuated from 1.5 to $1.6^{\circ} \mathrm{C}$. In the South Central Coast, Central Highlands and South, temperature ranged from 1.3 to $1.4^{\circ} \mathrm{C}$. By the end of the century, the temperature increased mainly from 1.9 to $2.4^{\circ} \mathrm{C}$ in the North and from 1.7 to $1.9^{\circ} \mathrm{C}$ in the South.

Following the RCP8.5 scenario, at the beginning of the century, the average annual temperature nationwide had a common increase from 0.8 to $1.1^{\circ} \mathrm{C}$. By mid-century, the common increase was from 1.8 to $2.3^{\circ} \mathrm{C}$. The temperature in the northern area increased from 2.0 to $2.3^{\circ} \mathrm{C}$ and from 1.8 to $1.9^{\circ} \mathrm{C}$ in the South. By the end of the century, the temperature in the North increased from 3.3 to $4.0^{\circ} \mathrm{C}$ and in the South from 3.0 to $3.5^{\circ} \mathrm{C}$ (Table 3).

Precipitation: According to scenario RCP4.5, at the early century, the annual rainfall tended to increase in most of the country, common from 5 to $10 \%$. By mid-century, the increase was mainly from 5 to $15 \%$. Some coastal provinces in the Northern Delta, North Central Coast and Central region might increase by over $20 \%$. By the end of the century, the annual rainfall variation had the same distribution as the middle of the century, but the area with an increase of over $20 \%$ was more extensive.

In line with the RCP8.5 scenario, at the beginning of the century, the annual rainfall tended to increase in most of the country, ranging from 3 to $10 \%$. In the middle of the century, the uptrend was similar to the RCP 4.5 scenario. It is noticeable that by the end of the century, the maximum increase could be over $20 \%$ in most of the North, Central and Central regions, a part of the South and the Central Highlands.

Based on data on temperature and precipitation, the amount of recharge and evaporation is calculated as input data to simulate groundwater resource changes corresponding to climate change scenarios (Table 4) (Dave et al., 2005; Zekâi, 2015; Wayan, 2017; Guillaume et al., 2017).

3.4.1 Scenario RCP4.5. In the period 2016-2035 of the scenario RCP4.5, the amount of recharge and evaporation both increase but not too different, so the simulation results show that the potential exploitation amount is similar to the current simulation. Over time, there is a strong increase and a rather large difference between the replenishment and evaporation (evaporation > evaporating), leading to a decrease in the amount of potential exploitable water in the area. Especially in the period 2080-2099, the amount of potential exploited water has a negative value; this shows a groundwater scarcity in the study area, although the exploitation reserve remains unchanged over time.

Figure 5(a) shows the increase as well as the difference between the recharge and evaporation over the stages in the RCP4.5 scenario. The amount of evaporation is increasing and outstripping the recharge, leading to the reduction and depletion of water resources in the area. Figure 5(b) shows the amount of potential exploitable water simulated under the RCP4.5 scenario for each period. In the period of 2016-2035, no significant change compared to the present has been detected, while in the period of 2046-2069, potential reserves have shown signs of sharp decline due to climate change, which increases the loss of water through evaporation. By the third period, the potential exploitation shows signs of deficiency with negative values in the simulation (Table 5 ).

3.4.2 Scenario RCP8.5. In the RCP8.5 scenario, the simulation for the period 2016-2035 shows that the potential exploited water volume is almost just enough for the water demand in the area. In the period 2046-2069, the shortage of water resources becomes more and more serious, culminating in the period 2080-2099, with a relatively large amount of evaporation (nearly twice the amount of replenishment) leading to a serious water scarcity. 
Table 3.

Changes of temperature and rainfall according to climate change scenario in Dak Lak 
FEBE 2,1

\section{4}

Table 4.

The amount of recharge and evaporation for groundwater in Dak Lak in response to climate change scenario
Figure 6(a) shows a rather large difference between evaporation and replenishment, especially from the period 2046-2069 to the period 2080-2099; this is even more evident, causing the scarcity of water sources for living and production needs of the people in the region. Figure 6(b) shows the amount of potential exploitable water simulated under the RCP8.5 scenario for each period. Similar to the RCP4.5 scenario, the potential mining reserves tend to decrease in the first period. However, the decline tends to accelerate because of more complex

\begin{tabular}{|c|c|c|c|c|c|c|}
\hline Variables & $\begin{array}{l}2016- \\
2035\end{array}$ & $\begin{array}{c}\text { RCP4.5 } \\
2046- \\
2069\end{array}$ & $\begin{array}{l}2080- \\
2099\end{array}$ & $\begin{array}{l}2016- \\
2035\end{array}$ & $\begin{array}{c}\text { RCP8.5 } \\
2046- \\
2069\end{array}$ & $\begin{array}{l}2080- \\
2099\end{array}$ \\
\hline Increase rainfall (\%) & 6.5 & 7.6 & 10.1 & 5.3 & 8.7 & 11.4 \\
\hline Increase rainfall (mm) & 117.0 & 136.8 & 181.8 & 95.4 & 156.6 & 205.2 \\
\hline Increase recharge $(\%)$ & 1.6 & 1.9 & 2.5 & 1.3 & 2.2 & 2.9 \\
\hline Increase recharge $(\mathrm{mm})$ & 29.3 & 34.2 & 45.5 & 23.9 & 39.1 & 51.3 \\
\hline Increase temperature $\left({ }^{\circ} \mathrm{C}\right)$ & 0.7 & 1.4 & 1.8 & 0.9 & 1.9 & 3.3 \\
\hline $\begin{array}{l}\text { Increase evapotranspiration } \\
(\%)\end{array}$ & 2.9 & 5.8 & 7.5 & 3.8 & 7.9 & 13.8 \\
\hline $\begin{array}{l}\text { Increase evapotranspiration } \\
(\mathrm{mm})\end{array}$ & 21.0 & 42.0 & 54.0 & 27.0 & 57.0 & 99.0 \\
\hline
\end{tabular}

Figure 5.

The change of recharge and evaporation (a), and potential reserves (b) simulated under the RCP 4.5 scenario
Table 5.

Simulation results of groundwater in Dak Lak with scenario RCP4.5

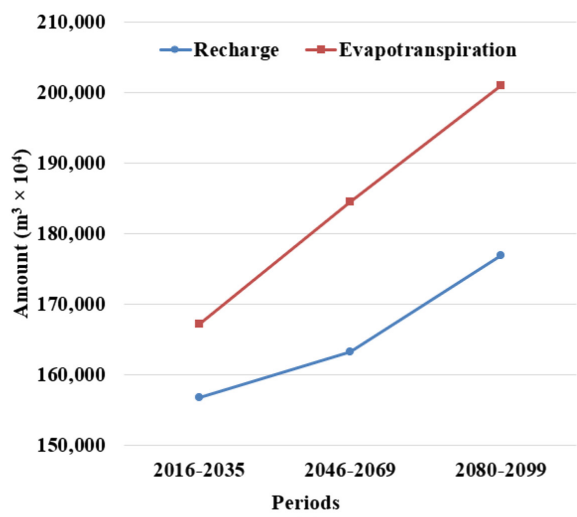

(a)

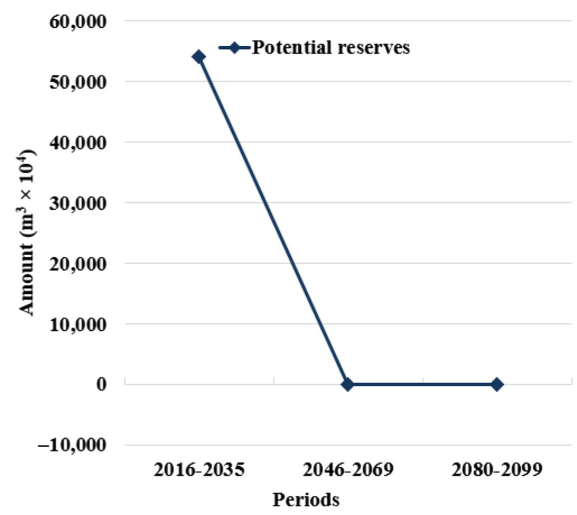

(b)

\begin{tabular}{lrrrrrr}
\hline & \multicolumn{2}{c}{$2016-2035$} & \multicolumn{2}{c}{$2046-2069$} & \multicolumn{2}{c}{$2080-2099$} \\
Variables $\left(\mathrm{m}^{3} \times 10^{4}\right)$ & \multicolumn{1}{c}{ In } & \multicolumn{1}{c}{ Out } & \multicolumn{1}{c}{ In } & \multicolumn{1}{c}{ Out } & \multicolumn{1}{c}{ In } & \multicolumn{1}{c}{ Out } \\
\hline (1) Storage & $257,568.5$ & $83,083.6$ & $25,7057.4$ & $86,575.9$ & $257,233.2$ & $52,624.9$ \\
(2) Constant head & $156,070.3$ & $129,988.6$ & $131,691.5$ & $141,325.6$ & $107,898.5$ & $135,357.9$ \\
(3) Pumping well & 0.0 & $22,520.4$ & 0.0 & $22,520.5$ & 0.0 & $22,926.9$ \\
(4) River leakage & $12,629.6$ & $126,119.6$ & $12,728.4$ & $129,784.4$ & $11,696.8$ & $141,980.2$ \\
(5) Evapotranspiration & 0.0 & $167,249.2$ & 0.0 & $184,586.0$ & 0.0 & $200,943.0$ \\
(6) Recharge & $156,754.0$ & 0.0 & $163,210.5$ & 0.0 & $176,918.2$ & 0.0 \\
(7) Lake seepage & 136.7 & 32.2 & 142.7 & 31.8 & 93.9 & 36.7 \\
Total (1+2+3+4+5+6+7) & $583,159.2$ & $528,993.6$ & $564,830.5$ & $564,824.2$ & $553,840.7$ & $553,869.7$ \\
Potential reserves (Total In- & $54,165.5$ & & 6.3 & & -29.0 \\
Total Out) & \multicolumn{7}{c}{} \\
\end{tabular}




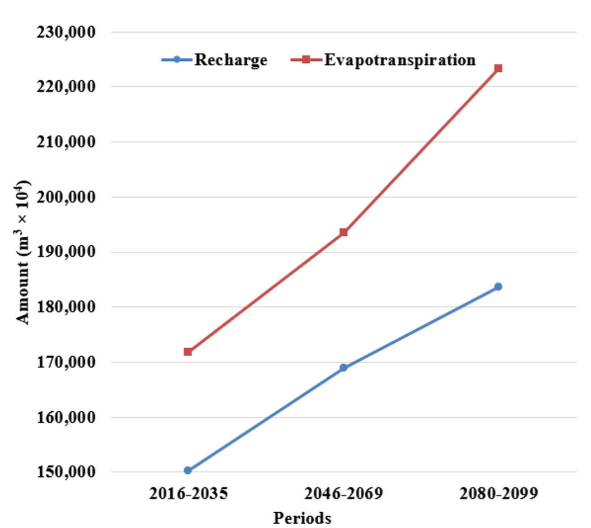

(a)

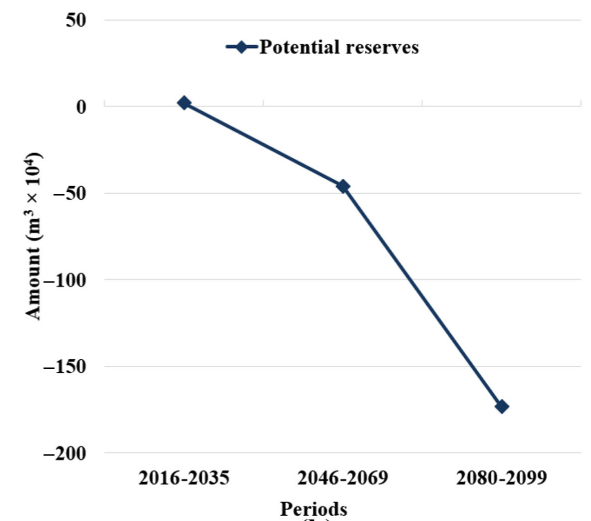

(b)
Groundwater simulation in Dak Lak

climate change conditions. In the period 2016-2035, the potential exploitation volume has almost disappeared in the study area. Potential reserves show signs of shortage in the period 2046-2069, and by the last period, the water scarcity is more severe (Table 6).

\section{Conclusion}

Groundwater sources in the studied region are abundant and capable of meeting people's needs for everyday living and production. Due to the shortage of water sources during the dry season, however, water exploitation is unplanned and out of control, resulting in the depletion of water resources. As a result, particular strategies for agricultural expansion, as well as efficient exploitation and use of water resources, are critical for assuring the long-term development of water resources. Simultaneously, avoid unplanned and overwhelming production, which will put pressure on water supplies, particularly groundwater.

Because the province's rainwater reserves are quite vast, it is vital to take measures to amass and utilize them wisely to meet the people's water needs. Furthermore, because reservoirs are not fully involved in the water equivalent process, it is vital to exploit and utilize reservoirs' ability to store and deliver water to regulate water sources and reduce pressure on underground water sources.

The application of the MODFLOW model to Dak Lak province demonstrates that, despite limited data, particularly drilling hole data for subterranean water research, the model's

\begin{tabular}{|c|c|c|c|c|c|c|c|}
\hline \multirow[b]{2}{*}{ Variables $\left(\mathrm{m}^{3} \times 10^{4}\right)$} & \multicolumn{2}{|c|}{$2016-2035$} & \multicolumn{2}{|c|}{$2046-2069$} & \multicolumn{2}{|c|}{ 2080-2099 } & \\
\hline & In & Out & In & Out & In & Out & \\
\hline (1) Storage & $258,234.5$ & $82,353.0$ & $257,794.2$ & $76,331.8$ & $257,268.4$ & $66,352.5$ & \\
\hline (2) Constant head & $111,672.6$ & $129,562.8$ & $104,977.0$ & $128,690.5$ & $103,907.3$ & $126,327.7$ & \\
\hline (3) Pumping well & 0.0 & $22,520.5$ & 0.0 & $22,714.7$ & 0.0 & $22,814.9$ & \\
\hline (4) River leakage & $12,827.6$ & $126,908.2$ & $13,135.4$ & $123,789.4$ & $13,880.0$ & $120,078.4$ & \\
\hline (5) Evapotranspiration & 0.0 & $171,813.2$ & 0.0 & $193,452.2$ & 0.0 & $223,389.7$ & \\
\hline (6) Recharge & $150,315.0$ & 0.0 & $168,909.1$ & 0.0 & $183,603.7$ & 0.0 & \\
\hline (7) Lake seepage & 142.4 & 32.3 & 148.1 & 31.4 & 160.5 & 30.12 & \\
\hline $\begin{array}{l}\text { Total } \\
(1+2+3+4+5+6+7)\end{array}$ & $533,192.0$ & $533,190.0$ & $544,963.8$ & $545,009.9$ & $558,819.9$ & $558,993.3$ & Simulation results of \\
\hline $\begin{array}{l}\text { Potential reserves (Total In - } \\
\text { Total Out) }\end{array}$ & & & & & & 73.4 & $\begin{array}{r}\text { groundwater in Dak } \\
\text { Lak with } \\
\text { scenario RCP8.5 }\end{array}$ \\
\hline
\end{tabular}


FEBE 2,1

calculation results have demonstrated its reliability and great potential for use in other similar places. The use of the model in conjunction with other data extraction modules is a useful input for creating underground flow module maps for various time periods. The large impact of recharge and evaporation on groundwater supplies and water balance in the research area is demonstrated by simulations of climate change scenarios RCP4.5 and RCP8.5. There were indications of depletion and lack of water supplies in daily life and productivity in Dak Lak province from the middle of the 21st century onward.

To meet the needs of everyday living and agricultural production during the dry season, it is required to invest in and upgrade the irrigation infrastructure as well as expand rainwater storage. Furthermore, it is advised that modern technology be used in irrigation and production in conjunction with public awareness campaigns to encourage the efficient use of water resources and reduce the waste of groundwater resources. On the other hand, this finding opens up the possibility of projecting changes in subterranean water reserves as a result of changes in rain, infiltration and evaporation conditions as a result of climate change, as well as groundwater extraction choices in the research area and related places. More specifically, the success of simulating water level elevations and groundwater dynamics provides a good foundation for the remaining MODFLOW modules to calculate and predict the salinity and pollution of aquifers based on water use scenarios, thereby assisting Dak Lak province in fulfilling its mission of resource protection and sustainable development.

\section{References}

Ahmad, A. (2000), "An institutional analysis of changes in land use pattern and water scarcity in Dak Lak province, Vietnam", Institutions, Livelihoods and the Environment, Vol. 7, September, pp. 1-30.

Anh, T.N., Hoang, N.T., Son, N.T. and Giang, N.T. (2009), "The applicability of the MODFLOW model to calculate and forecast groundwater reserves in the plains of Quang Tri province", VNU Science Journal, Science and Technology, Vol. 25 No. 3S, pp. 372-380.

Dave, D., Dirk, R., Jozef, D., Phong, T.A. and Loi, H.V. (2005), "Groundwater extraction for irrigation of Coffea canephora in Ea Tul watershed, Vietnam - a risk evaluation", Agricultural Water Management, Vol. 73 No. 1, pp. 1-19, doi: 10.1016/j.agwat.2004.10.003.

Ellen, M., François, N. and Pierre, P.P. (2015), Vietnam to Produce More Coffee with Less Water towards a Reduction of the Blue Water Footprint in Coffee Production - Hydrogeological Study of the Basaltic Plateau in Dak Lak Province, Vietnam, Centre d'hydrogéologie et de géothermie (CHYN), available at: https://www.hrnstiftung.org/wp-content/uploads/2017/08/DAK-LAKbaseline-study-CHYN-FINAL.compressed.pdf.

Feng, J., Liu, G. and Zhao, Q. (2010), "Application of visual MODFLOW to the dynamic change and simulation of deep groundwater in Dezhou City, China", Advanced Materials Research, Vols 113-116, pp. 1025-1030, doi: 10.4028/www.scientific.net/AMR.113-116.1025.

Fortunel, F. (2000), “Le café au Viêt Name”, Cahiers de géographie du Québec, Vol. 46 No. 127, p. 113, doi: 10.7202/023029ar.

Guillaume, L., Somphasith, D., Sinxay, V. and Paul, P. (2017), "Regional assessment of groundwater recharge in the lower Mekong basin”, Hydrology, Vol. 4 No. 4, pp. 1-18, doi: 10.3390/ hydrology 4040060 .

Hiep, H.V. and Ty, T.V. (2012), "Assessment of groundwater resources in Tra Vinh province using modflow model”, Science Magazine, pp. 42-51.

Hieu, B.N.Q.P. (2006), "Balance of water use in Basalt-central highlands", Research Gate, November 2006.

Hoori, A. (2020), Geohydrology: Groundwater. 2nd edn, Encyclopedia of Geology, 2nd ed., Academic Press, Oxford, pp. 408-415, available at: https://www.sciencedirect.com/science/article/pii/ B9780124095489123887. 
Japan International Cooperation Agency (JICA) (2018), "Data collection survey on water resources management in Central Highlands", April, p. 167.

Jeremy, C. and Jeff, B. (2005), Managing Groundwater Access in the Central Highlands (Tay Nguyen), Australian Centre for International Agricultural Research (ACIAR), Vietnam.

Mary, P.A., William, W.W. and Randall, J.H. (2015), "Spatial discretization and parameter assignment", in Applied Groundwater Modeling, pp. 181-255, doi: 10.1016/b978-0-08-091638-5.00005-5.

Michael, G.M. and Arlen, W.H. (1988), "A modular three-dimensional finite-difference groundwater flow model, techniques of water-resources investigations report, 06-A1”, U.S, G. P. O., p. 588, doi: 10.3133/twri06A1.

Nasrin, K., Meftah Halagh, M. and Amirahmad, D. (2013), "Numerical simulation of groundwater level using MODFLOW software (A case study: Narmab watershed, Golestan province)", International Journal of Advanced Biological and Biomedical Research, Vol. 1 No. 8, pp. 858-873.

Nawapi; Resource base and environment (2015), "Report on the current state of the environment in Dak Lak", Vietnam, 2011-2015.

Trang, N.T.M., Hồng, L.Đ. and Trí, V.K. (2016), "Forecasting groundwater flow in Con Son island under climate change scenario", Journal of Irrigation Science and Technology, Vol. 33, pp. 1-11.

Trung, T.D., Duc, D.D., Anh, N.K.N., Anh, T.N., Huong, N.V. and Tu, N.T. (2019), "Calculating underground water reserves by mathematical modeling method: a study for the coastal plain of Quang Nam province”, Research Gate, Vol. 01 No. 45, pp. 138-148.

USGS (1997), "Modeling ground-water flow with MODFLOW and related programs", U.S Geological Survey, available at: https://pubs.usgs.gov/fs/FS-121-97/fs-121-97.pdf.

Waterloo Hydrogeologic (2018a), "Airport numerical model with transport visual MODFLOW flex", pp. 0-57, available at: https://www.waterloohydrogeologic.com/help/vmod-flex/index.html?vm_ tutorial_airportnummodel_witht.htm.

Waterloo Hydrogeologic (2018b), "User's manual visual MODFLOW Flex 5.1", Waterloo Hydrogeologic, p. 695.

Wayan, I.S. (2017), "Effect of the climate change on groundwater recharging in Bangga watershed, Central Sulawesi, Indonesia”, Environmental Engineering Research, Vol. 22 No. 1, pp. 87-94, doi: 10.4491/eer.2016.127.

World Bank (2019), Environmental and Social Impact Assessment Report Subproject: Dak Lak Dam Rehabilitation and Safety Improvement Phase 1, Dak Lak Department of Agriculture and Rural Development, Dak Lak, available at: https://documents1.worldbank.org/curated/pt/ 207301568869624598/pdf/Environmental-and-Social-Impact-Assessment-for-Dak-Lak-DamRehabilitation-and-Safety-Improvement-Phase-One.pdf.

Zekâi, Ş. (2015), "Climate change, droughts, and water resources", in Applied Drought Modeling, Prediction, and Mitigation, pp. 321-391, doi: 10.1016/b978-0-12-802176-7.00006-7.

\section{Further reading}

GSO (2019), Statistical Yearbook of Vietnam, General Statistics Office of Vietnam, Hanoi, ISBN 9786047515530 .

\section{Corresponding author}

Nguyễn An Bình can be contacted at: nabinh@hcmig.vast.vn

For instructions on how to order reprints of this article, please visit our website:

www.emeraldgrouppublishing.com/licensing/reprints.htm

Or contact us for further details: permissions@emeraldinsight.com
Groundwater simulation in Dak Lak 